\title{
[5्चSPCR
}

\section{Analgesic Activity of Ethanolic Extracts of Karika Leaves (Carica pubescens) In Vivo}

\section{Aktivitas Analgesik Ekstrak Etanol Daun Karika (Carica pubescens) Secara In Vivo}

Heru Sasongko ${ }^{1,3^{*}}$, Sugiyarto $^{2,3}$, Yeni Farida ${ }^{1}$, Nur Rohman Efendi ${ }^{1}$, Diah Pratiwi ${ }^{1}$, Ahmad Dwi Setyawan $^{2,3}$ and Tetri Widiyani ${ }^{2,3}$

1 Department of Pharmacy, Faculty of Mathematics and Natural Sciences, Universitas Sebelas Maret. J1. Ir. Sutami 36A Surakarta 57 126, Central Java, Indonesia.

Department of Biology, Faculty of Mathematics and Natural Sciences, Universitas Sebelas Maret. Jl. Ir. Sutami 36A Surakarta 57 126, Central Java, Indonesia.

3 Biodiversity Reaserch Group, Department of Biosains Postgraduate Programe, Universitas Sebelas Maret. Jl. Ir. Sutami 36A Surakarta 57 126, Central Java, Indonesia.

*email korespondensi: heru_sasongko@staff.uns.ac.id

Abstract: Karika (Carica pubescens)is a typical plant of the Dieng plateau. Previous study showed that Caricapubescenscontains chemical compound such as flavonoid that play role in analgesic activity. This study was aimed to determine the analgesic activity of etanolic extracts of karika leaves) in vivo using writhing method. The study was conducted on 25 male mice strain Swiss-Webster (20-30 g, 2-3 months) that were randomly divided into 5 groups. Group I was given distilled water $1 \mathrm{~mL}$ (p.o) as negative control, group II was given tramadol $50 \mathrm{mg} / \mathrm{kgBW}$ (p.o) as positive control, and group III-V received an etanolic extracts of karika leaves in 3 doses, i.e. $20 \mathrm{mg} / \mathrm{kgBW}, 40 \mathrm{mg} / \mathrm{kgBW}$, and $80 \mathrm{mg} / \mathrm{kgBW}$ (p.o), respectively. Acetic acid 0,5\% (v/v) was used as pain inductor. The writhe was observed within 1 hour. Data analysis was carried out by using one way ANOVA. The result showed that the ethanol extract of leaves Karika (Carica pubescens) have activity as an analgesic at a dose of $20 \mathrm{mg} / \mathrm{kg}, 40 \mathrm{mg} / \mathrm{kg}$ and $80 \mathrm{mg} / \mathrm{KgBW}$ (p <0.05), chemically induced, where a dose of $80 \mathrm{mg} / \mathrm{KgBW}$ (p.o) produce the most high analgesic activity.

Abstrak: Karika (Caricapubescens) merupakan tanamankhas datarantinggiDieng yang termasukdalamfamiliCaricaceaedansatu genus dengan pepaya. Penelitian sebelumnya menunjukkan bahwa Carica pubescens memiliki kandungan kimia berupa flavonoid yang berperan sebagai analgesik. Penelitian ini bertujuan untuk mengetahui aktivitas analgesik ekstrak etanol daun karika (Carica pubescens) secara in vivo dengan menggunakan metode geliat. Pengujian dilakukan terhadap 25 ekor mencit jantan galur Swiss-Webster (20-30 g, 
2-3 bulan) yang diacak menjadi 5 kelompok. Kelompok I diberi aquades $1 \mathrm{~mL}$ (p.o) sebagai kontrol negatif, kelompok II diberi tramadol dosis $50 \mathrm{mg} / \mathrm{kgBB}$ (p.o) sebagai kontrol positif, dan kelompok III-V diberi ekstrak etanol daun karika dengan dosis secara berturut-turut $20 \mathrm{mg} / \mathrm{kgBB}, 40 \mathrm{mg} / \mathrm{kgBB}$, dan $80 \mathrm{mg} / \mathrm{kgBB}$ (p.o). Asam asetat 0,5\% (v/v) digunakan sebagai induktor nyeri. Geliat diamati selama 1 jam. Analisis data dilakukan dengan menghitung persentase daya analgetik dari jumlah kumulatif geliat mencit, kemudian dianalisis dengan one way ANOVA. Dari hasil penelitian diketahui bahwa ekstrak etanol daun karika (Caricapubescens) mempunyai aktivitas sebagai analgetik pada dosis $20 \mathrm{mg} / \mathrm{KgBB}, 40 \mathrm{mg} / \mathrm{KgBB}$ dan $80 \mathrm{mg} / \mathrm{KgBB}(\mathrm{p}<0.05)$ yang diinduksi secara kimia, dimana dosis $80 \mathrm{mg} / \mathrm{KgBB}$ menghasilkan aktivitas analgetik yang paling tinggi.

Keywords:Ethanolic Extracts, Caricapubescens, Analgesic, in vivo

\section{Pendahuluan}

Nyeri didefinisikan sebagai suatu pengalaman sensorik dan emosional yang berkaitan dengan kerusakan jaringan (Merskey dan Bogduk, 1994). Senyawa yang dalam dosis terapeutik meringankan atau menekan rasa nyeri tanpa memiliki kerja anestesi umum disebut sebagai analgesik (Mutschler, 1991). Analgesik yang saat ini sering digunakan adalah non-steroidal antiinflammatory drugs (NSAIDs), opioid, dan antidepresan. NSAIDs adalah obat yang sering digunakan dalam terapi karena mempunyai efek analgetik dan antiinflamasi sekaligus. Efek samping NSAIDs terutama terjadi pada gastrointestinal, hematologis, dan renal sehingga penggunaannya harus dibatasi (Sigh et al, 2015). Beberapa tahun ini studi tentang tanaman herbal marak dilakukan, mengingat efisiensi tanaman herbal dan kekhawatiran akan efek samping obat kimia (Ripa et al, 2015). Keuntungan penggunaan obat dari bahan alam diantaranya efektif khasiatnya, efek toleransi yang baik, efek samping dan alergi cenderung sedikit (Hasan et al, 2015).

Karika (Carica pubescens) merupakan tumbuhan khas di dataran tinggi Dieng yang termasuk dalam familia Caricaceae dan satu genus dengan papaya (Laily, 2011). Dalam daun karika (Carica pubescens) selain terdapat vitamin C juga terdapat senyawa fitokimia yaitu flavonoid, alkaloid, tannin dan fenol (Novalina et al 2013). Bagi manusia, flavonoid berguna sebagai antioksidan, antimikrobia, antibakteri, antivirus (Harborne and Williams, 2000), antiinflamasi, antialergi, antimutagenik, antiklastogenik, antikanker, dan antiplatelet (Setyawan dan Darusman, 2008).Flavonoid juga berperan sebagai analgesik dengan cara menghambat kerja enzim siklooksigenase dengan cara mengurangi produksi prostaglandin oleh asam arakidonat sehingga mengurangi rasa nyeri. Selain itu flavonoid juga menghambat degranulasi neutrofil sehingga akan menghambat pengeluaran sitokin, radikal bebas, serta enzim yang berperan dalam peradangan (Christiana et al, 2012).

Sampai saat ini belum ada penelitian tentang aktivitas analgetik dari daun Carica pubescens. Pada daun Carica papaya yang merupakan satu family dari Carica pubescens telah diketahui aktivitasnya sebagai analgetik dengan dosis efektif 2,4 g/KgBB (Octavianus, 2014). Penelitian 
oleh Anaga and Onehi (2010) menunjukkan bahwa Carica papaya pada dosis $20 \mathrm{mg} / \mathrm{kg}$ mempunyai aktivitas sebagai antinociceptiveatau antinyeri.Penelitian ini bertujuan untuk mengetahui aktivitas analgetik daun karika (Carica pubescens) pada mencit dengan metode geliat (writhing test).

\section{Bahan dan Metode}

\subsection{Waktu dan tempat penelitian}

Penelitian ini dilaksanakan pada bulan Maret-April 2016 di Laboratorium Farmasetika FMIPA UNS untuk ekstraksi tanaman dan Laboratorium Farmakologi FMIPA UNS untuk uji analgetik.

\subsection{Bahan dan alat}

Dalam penelitian ini digunakan 25 ekor mencit putih jantan galur Swiss-webster dengan usia 2-3 bulan dan berat 20-30 gram. Bahan percobaan berupa daun karika dari lereng Pegunungan Lawu, etanol $70 \%$ (teknis), aquades, $\mathrm{NaCl}$, asam asetat $0,5 \%$, dan tramadol $50 \mathrm{mg}$ (Kimia Farma ${ }^{\circledR}$ ).

Alat-alat yang digunakan meliputi neraca analitik, pisau, ayakan, oven, stirer, cawan uap, waterbath, blender, stopwatch, kertas saring, kandang pengamatan, spuit injeksi, sonde oral, dan alat-alat gelas (Pyrex Iwaki ${ }^{\circledR}$ ).

\section{Cara kerja}

\subsection{Rancangan penelitian}

Penelitian ini menggunakan rancangan acak lengkap (RAL) dengan lima macam perlakuan, masing-masing perlakuan tiga replikasi.

\subsection{Ekstraksi daun karika}

Daun karika dibersihkan dan dikeringkan dengan oven pada suhu $50^{\circ}$ C.Setelah kering daun dipotong kecil-kecil, diserbuk dan diayak dengan ayakan 40 mesh.Serbuk diekstrak dengan maserasi sederhana menggunakan etanol 70\% selama 5 hari. Selama proses perendaman, wadah disimpan pada suhu kamar dan terlindung dari cahaya matahari. Setelah proses perendaman selesai dilakukan penyaringan hingga didapat maserat. Ampas dari proses penyaringan diremaserasi dengan pelarut yang sama hingga didapat hasil maserat yang jernih. Maserat dievaporasi dengan waterbath hingga diperoleh ekstrak kental.Untuk pengujian, ekstrak kental di suspensikan dalam larutan $\mathrm{CMC} \mathrm{Na} 0,5 \%$

\subsection{Persiapan hewan uji}

Sebelum perlakuan, mencit diadaptasikan terhadap lingkungan dan makanan selama 1 minggu dan selama 18 jam sebelum pemberian bahan uji mencit dipuasakan namun tetap diberi minum. 


\subsection{Uji daya analgetik}

Sebanyak 25 ekor mencit jantan dibagi dalam 5 kelompok perlakuan dengan ketentuan sebagai berikut.

Kelompok I : diberi suspensi CMC Na 0,5\% $1 \mathrm{~mL}$ (kontrol negatif)

Kelompok II : diberi tramadol dosis $50 \mathrm{mg} / \mathrm{kgBB}$ (kontrol positif)

Kelompok III : diberi ekstrak etanol daun karika dosis $20 \mathrm{mg} / \mathrm{kgBB}$

Kelompok IV : diberi ekstrak etanol daun karika dosis $40 \mathrm{mg} / \mathrm{kgBB}$

Kelompok V : diberi ekstrak etanol daun karika dosis $80 \mathrm{mg} / \mathrm{kgBB}$

Dosis ekstrak etanol daun karika ditetapkan secara bertingkat berdasarkan penelitian pendahuluan pada daun Carica papayasebagai antinociceptive atau antinyeri dengan mempertimbangkan kesamaan famili (Anaga and Onehi, 2010)

Mencit sebagai hewan uji diberi ekstrak etanol daun karika secara peroral. Setelah 15 menit perlakuan dilanjutkan dengan diinduksi nyeri dengan asam asetat $0,5 \%$ secara intraperitonial, dan ditempatkan pada kotak perlakuan. Jumlah geliat dihitung pada masing-masing kelompok perlakuan.Satu geliat ditandai dengan kaki mencit ditarik kedepan dan belakang disertai abdomen yang menyentuh lantai.Jumlah geliat dari tiap kelompok dirata-rata dan dibandingkan antara kelompok perlakuan dan kontrol.Jumlah geliat yang lebih sedikit dari kelompok kontrol menandakan adanya aktivitas analgetik pada hewan uji (Goenarwoet al., 2011).

\subsection{Perhitungan daya analgetik dan efektivitas analgetik}

Besarnya penghambatan jumlah geliat dihitung dengan persamaan Handerson dan Forsalt yaitu :

$$
\% \text { Proteksi geliat }=100-[(\mathrm{P} / \mathrm{K}) \times 100 \%]
$$

Keterangan :

$\mathrm{P}=$ jumlah kumulatif geliat hewan uji setelah pemberian obat yang ditetapkan

$\mathrm{K}=$ jumlah kumulatif geliat hewan uji kontrol negative (Turner, 1965)

Perhitungan efektivitas analgetik dilakukan berdasarkan persamaan berikut.

Efektivitas analgetik $=\frac{\% \text { proteksibahanuji }}{\% \text { proteksitramadol }} \times 100 \%$

\subsection{Analisis Data}

Data hasil pengamatan dikumpulkan dan disajikan dalam bentuk tabel, grafik dan analisis statistik uji one way ANOVA (Analysis of Variance). 


\section{Hasil dan Pembahasan}

Pada penelitian ini sampel yang digunakan adalah daun karika yang telah dikeringkan menjadi simplisia kering. Randemen hasil ekstraksi menggunakan etanol $70 \%$ didapatkan sebesar27,13\%.Penelitian yang sudah pernah dilakukan bahwa ektrak etanol 70\% daun Karika (Carica pubescens) diketahui mengandung metabolit sekunder berupa flavonoid, alkaloid, tannin dan fenol (Novalina dkk, 2013).Pemberian asam asetat 1\% pada hewan percobaan yang digunakan sebagai penginduksi nyeri karena menyebabkan rasa sakit akibat iritasi yang berat pada mukosa membran rongga perut sehingga kaki tertarik ke belakang, meregang dan abdomen menyentuh dasar plate form (Afrianti dkk, 2014).Pada kontrol negatif diberikan suspensi CMC $\mathrm{Na}$ 0,5\%1 ml untuk melihat efek geliatan tanpa diberi obat sedangkan pembanding diberikan larutan tramadol dengan dosis $50 \mathrm{mg} / \mathrm{kgBB}$ yang merupakan obat analgetik potensial(Kaneko et al, 2014). Hasil uji farmakologi terhadap persen (\%) proteksi geliat (\%PG) dapat dilihat pada gambar 1 .

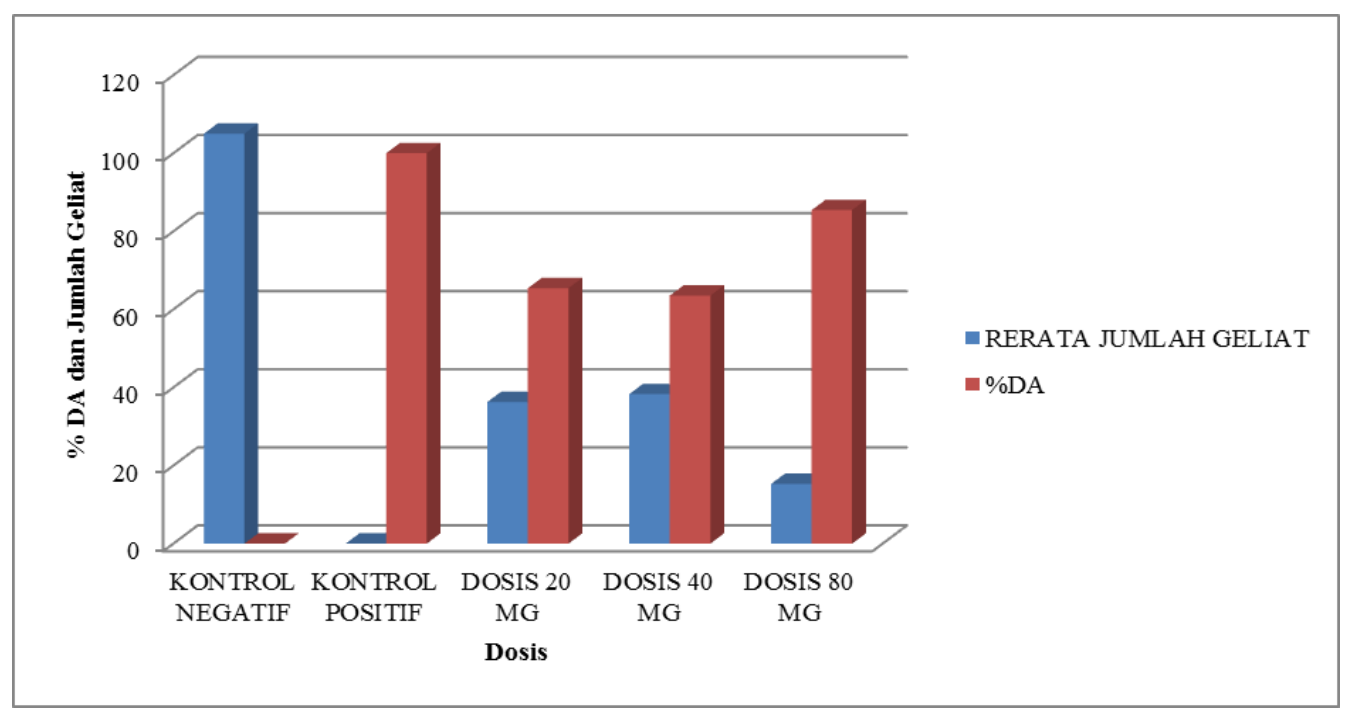

Gambar 1. Uji \% Daya Analgetik dari kumulatif jumlah geliat

Berdasarkan perhitungan \% proteksi geliat (\%PG) menggunakan perhitunganTurner (1965), terlihat jelas seperti tertera pada gambar 1 bahwa daun karika pada dosis $20 \mathrm{mg} / \mathrm{KgBB}, 40$ $\mathrm{mg} / \mathrm{KgBB}$ dan $80 \mathrm{mg} / \mathrm{KgBB}$ mempunyai aktivitas analgetik. Pada kontrol negatif dimana tidak diberikan perlakuan ekstrak dan hanya diberikan suspensi CMC Na 0,5\% memberikan efek proteksi geliat yang tidak ada sehingga memiliki \%PGsebesar $0 \%$. Hal ini menunjukkan bahwa hanya dengan pemberian CMC Na 0,5\% tidak memberikan efek analgetik pada perlakuan mencit. Kontrol positif dimana kelompok uji diberikan tramadol secara peroral memberikan \% PG yang sangat tinggi yaitu 100\%.Hal ini sesuai dengan khasiat dari Tramadol yang yaitu memberikan efek antinyeri baik secara akut maupun kronis (Kaneko et al, 2014). Pada kelompok perlakuan dengan pemberian secara oral ekstrak karika dosis $20 \mathrm{mg} ; 40 \mathrm{mg}$ dan $80 \mathrm{mg}$ masing masing memberikan \%PG secara berturut - turut 65,4\%; 63,5\% dan 85,4\%. Diketahui dosis 20 dan $40 \mathrm{mg}$ hampir memiliki \%PG yang sama, sedangkan dosis $80 \mathrm{mg} / \mathrm{KgBB}$ mencit memberikan \% PG yang paling tinggi dari semua dosis ekstrak yang diberikan. 
Dari uji statistik terhadap jumlah kumulatif geliat selama 1 jam menggunakan ANOVA satu arah, ekstrak etanol daun Karika (Carica pubescens) dengan dosis $20 \mathrm{mg} / \mathrm{KgBB}$ dan $40 \mathrm{mg} / \mathrm{KgBB}$, menghasilkan efek analgetik tidak berbeda nyata ( $>>0,05)$. Akan tetapi pada dosis $80 \mathrm{mg} / \mathrm{KgBB}$ menghasilkan efek analgetik yang berbeda bermakna $(\mathrm{p}<0,05)$.Ekstrak daun Karika (Carica pubescens) diketahui mengandung senyawa fitokimia yaitu flavonoid, alkaloid, tannin dan fenol (Novalina, 2013).Penelitian yang dilakukan pada daun Karica papaya (Carica papaya)yang merupakan satu familli dengan Karika (Carica pubescens) menunjukkan bahwa ektrak etanol daun papaya memiliki efek analgetik yang diujikan pada mencit (Octavianus dkk, 2014).Diketahui daun papaya mengandung flavonoid, dimana metabolit sekunder ini juga berperan dalam aktivitas analgetik melalui mekanisme kerja menghambat kerja enzim siklooksigenase yang berperan dalam sistesis prostaglandin sebagai mediator pembentuk rangsang nyeri (Afrianti, 2014).

\section{Kesimpulan}

Dari hasil penelitian diketahui bahwa ekstrak etanol daun Karika (Carica Pubescens) mempunyai aktivitas sebagai analgetik pada dosis $20 \mathrm{mg} / \mathrm{KgBB}, 40 \mathrm{mg} / \mathrm{KgBB}$ dan $80 \mathrm{mg} / \mathrm{KgBB}$ $(\mathrm{p}<0.05)$ yang diinduksi secara kimia, dimana dosis $80 \mathrm{mg} / \mathrm{KgBB}$ menghasilkan aktivitas analgetik yang paling tinggi.

\section{Ucapan Terimakasih}

Ucapan terimakasih disampaikan kepada Universitas Sebelas Maret atas bantuan pendanaan penelitian melalui Hibah PNBP dengan skema PUT MRG

\section{Conflicts of Interest}

The authors declare no conflict of interest 


\section{Daftar Pustaka}

Afrianti,R.,Yenti,R dan Meustika,D. Uji Aktifitas Analgetik Ekstrak Etanol Daun Pepaya (Carica papaya L.) pada Mencit Putih Jantan yang di Induksi Asam Asetat 1\%. Jurnal Sains Farmasi \& Klinis.2014; 1(1): 54-60

Anaga,A.O and Onehi, E.V.Antinociceptive and anti-inflammatory effects of themethanol seed extract of Carica papaya in mice andrats, African Journal of Pharmacy and Pharmacology. 2010; Vol. 4(4):140-144

Christiana,I.,Evacuasiany,E.,Hidayat,M.,The Analgetic Effect Of KayuRapat Bark Infusion (Parameria laevigata (Juss.) Moldenke) On Male Mice Treated With Thermal Induction. Jurnal Medika Planta. 2012; Vol. 2: No. 1.

Goenarwo,E., Chodidjah dan Susanto, H. Uji Efektifitas Analgetik Madu pada Tikus dengan Metoda Geliat Asetat, Journal of Madicine and Health. 2011; 3(1): 48-53.

Harborne, J.B. and Williams,C.A. Advances in flavonoid research since 1992. Phytochemistry.2000;55: 481-504.

Hasan,M.Y.,Mahamud,R.A., Rahman,S.,Ahmad,I., Rahmatullah,M. A Preliminary Report on Antihyperglycemic and Analgesic Properties of Methanol Extract Of Brassica Oleracea L. Var. Italica Sprouts.World Journal Of Pharmacy And Pharmaceutical Sciences. 2015; Vol 4, Issue 09: 225-234.

Kaneko,K.,Umehara,M.,Homan,T.,Okamoto,K.,Oka,M.,Oyama,T. The analgesic effect of tramadol inanimal models of neuropathic pain and fibromyalgia, Neuroscience Letters. 2014; 562: 28 33

Laily AN. 2011.Karakterisasi Carica pubescens Lenne \& K. Koch berdasarkan morfologi, kapasitas antioksidan, dan pola pita protein di Dataran Tinggi Dieng.[Tesis]. Universitas Sebelas Maret. Surakarta.

Merskey and Bogduk,N. 1994. Classification of Chronic Pain, Second Edition, IASP Task Force on Taxonomy. Seattle : IASP Press.

Mutschler,E. 1991. Dinamika Obat Farmakologi dan ToksikologiEdisi Kelima. Bandung Institut Teknologi Bandung.

Octavianus, S., Fatimawali dan Lolo.W.A. Uji Efek Analgetik Ekstrak Etanol Daun Pepaya (Carica papaya L) pada Mencit Putih Jantan (Mus mucculus). Pharmacon. 2014; Vol. 3 No. 2 : 87-92

Ripa, F.A.,Dash.P.R and Faruk,M.O. CNS Depressant, Analgesic And Anti-Inflammatory Activities Of Methanolic Seed Extract Of Calamus of Pharmacognosy And Phytochemistry.2015; 3(5): rotang Linn. Fruits In Rat. Journal 121-125.

Novalina, D.,Sugiyarto, Susolowati,A. Aktivitas Antibakteri Ekstrak Carica pubescens dari Dataran Tinggi Dieng terhadap Bakteri Penyebab Diare, El-VIVO. 2013; Nol Vol 1

Setyawan, A.D dan Darusman,L.K. REVIEW : Senyawa Biflavonoid pada Selaginella Pal. Beauv. dan Pemanfaatannya. Biodiversitas.2008;Volume 9: 64-81.

Singh,S., Sachan,A., Singh,H., Shankar,P., Kumar,D., Sachan,A.K., Nath,R And Dixit,R.K. Study Of Analgesic Activity Of Mucuna pruriens Extract On Swiss Albino Mice. World Journal Of Pharmaceutical Research.2015; Volume 4, Issue 5: 1124-1132.

Turner,R.A.1965, Screening Methods Pharmacology, Academic Press New York, 11-3116 